\title{
FLUKTUASI ASIMETRI DAN ABNORMALITAS PADA IKAN LELE DUMBO (Clarias sp.) YANG DIBUDIDAYAKAN DI KOLAM
}

\author{
Moh. Abduh Nurhidayat"), Odang Carman"), Enang Harris"), dan Komar Sumantadinata")
}

\begin{abstract}
ABSTRAK
Studi bertujuan untuk mengetahui fluktuasi asimetri dan abnormalitas pada ikan lele dumbo yang dipelihara di kolam. Sampel ikan dikumpulkan dari tiga daerah sentra budi daya di Jawa yaitu Sleman, Tulung Agung, dan Bogor masing-masing sebanyak 225 ekor. Organ tubuh berpasangan yang diamati dan dihitung adalah jumlah jari-jari lemah sirip dada, jumlah jari-jari lemah sirip perut, dan jumlah tapis insang pada lengkung insang bagian luar. Bilangan dan besaran asimetri dihitung dengan membandingkan keseimbangan sisi kiri dan kanan. Ikan yang organ tubuh berpasangan pada sisi kiri dan kanannya tidak tumbuh sama sekali, dipisahkan dari perhitungan asimetri. Hasil penelitian menunjukkan bahwa ikan lele dumbo memiliki fluktuasi asimetri dan abnormalitas yang tinggi. Nilai tertinggi fluktuasi asimetri besaran mencapai 8,93 dan fluktuasi asimetri bilangan mencapai 2,17; sedangkan abnormalitas tertinggi adalah 27,56. Hasil ini diduga karena silang dalam yang telah terjadi dalam beberapa generasi.
\end{abstract}

ABSTRACT: Fluctuating asymmetry and abnormality in cultured dumbo catfish (Clarias sp.). By: Moh. Abduh Nurhidayat, Odang Carman, Enang Harris, and Komar Sumantadinata

A study of meristic characters and physical abnormality on dumbo catfish was conducted to evaluate fluctuating asymmetry as an indicator of inbreeding depression. Samples were collected from three highly intensive breeding districts i.e. Sleman, Tulung Agung, and Bogor. A total of 225 fish from each district were evaluated by counting the number of rays in the pectoral fin and ventral fin as well as the number of spines on both of the outmost gill archs. The results indicated that dumbo catfish has a high level of fluctuating asymmetry as well as abnormality due to strong inbreeding depression. The highest values of overall magnitude asymmetry and number asymmetry were 8.93 and 2.17 respectively, while the abnormality was 27.56 .

KEYWORDS: catfish, fluctuating asymmetry, abnormality, inbreeding

\section{PENDAHULUAN}

Lele dumbo (Clarias sp.) merupakan ikan introduksi yang masuk pertama kali ke Indonesia tahun 1985. Lele dumbo sebagai ikan hibrida, yaitu hasil persilangan antara Clarias gariepinus dengan Clarias fuscus, pada awalnya mempunyai keunggulan dalam hal kecepatan tumbuh, derajat sintasan, jumlah telur, dan ukuran maksimal yang dapat dicapai.

Sejalan dengan berkembangnya usaha budi daya lele dumbo, saat ini petani telah merasakan adanya penurunan kualitas yang ditandai dengan rendahnya pertumbuhan dan sintasan, sehingga menyebabkan penurunan produksi. Rustidja (1999) menyatakan bahwa pada awal lele dumbo berkembang di Indonesia (1985), pemeliharaan benih ukuran 3--5 cm menjadi ukuran konsumsi dengan bobot berkisar antara 125-$150 \mathrm{~g} /$ ekor dapat dicapai dalam waktu 70 hari. Namun saat ini, dengan pola budi daya yang sama waktu pemeliharaannya menjadi sekitar 100 hari. Penurunan pertumbuhan dalam populasi ikan dapat disebabkan oleh menurunnya kualitas genetik. Leary et al. (1985) mengemukakan bahwa rendahnya kualitas genetik akan berakibat negatif terhadap sifat-sifat penting dalam budi daya ikan, antara lain menurunnya tingkat sintasan dan pertumbuhan. Fenomena ini dicirikan juga dengan meningkatnya individu yang asimetri dan abnormal. Hal ini terlihat pada perbedaan bentuk, ukuran, jumlah, dan ciri-ciri morfologi yang lain pada organ tubuh berpasangan antara organ bagian kiri dan bagian kanan (Wilkins et al., 1995).

Menurut van Valen (1962), adanya perbedaan fenotip pada individu untuk sifat meristik yang bilateral dapat menunjukkan fluktuasi asimetri, yaitu adanya perbedaan antara karakter sisi kiri dan sisi kanan yang menyebar secara normal dengan rataan mendekati nol sebagai akibat dari ketidakmampuan individu untuk berkembang secara tepat dan normal.

Berkaitan dengan itu dilakukan penelitian yang bertujuan untuk mengetahui tingkat asimetri dan abnormalitas ikan lele dumbo pada tiga daerah sentra 
budi daya lele dumbo di Pulau Jawa, yaitu Sleman, Tulung Agung, dan Bogor; melalui pengamatan karakter meristik bilateral.

\section{BAHAN DAN METODE}

Jumlah sampel yang diambil dari tiap daerah adalah 225 ekor ikan lele dumbo berukuran 75--150 g per ekor. Pengambilan sampel pada tiap daerah dilakukan dengan cara acak dari tiga tempat pembesaran lele, masing-masing 75 ekor. Pengangkutan dari daerah sampel ke tempat pengamatan di Balai Budidaya Air Tawar (BBAT), Sukabumi diusahakan tetap dalam keadaan hidup, yaitu pengangkutan dengan sistem terbuka menggunakan wadah berupa drum yang pada bagian atasnya berlubang.

Setibanya di BBAT, ikan sampel dimatikan dengan cara memotong bagian atas punggung yang berbatasan dengan bagian kepala (bagian kepala tidak sampai lepas dari badan). Kemudian organ dalam isi perut dikeluarkan/dibuang, untuk selanjutnya ikan sampel disimpan dalam freezer (suhu $-5^{\circ} \mathrm{C}$ ) agar tidak mengalami kerusakan pada organ tubuhnya, terutama organ yang diamati.

Organ tubuh berpasangan yang diamati dan dihitung adalah jumlah jari-jari lemah sirip dada, jumlah jari-jari lemah sirip perut, dan jumlah tapis insang pada lengkung insang bagian luar. Untuk penghitungan tersebut, terlebih dulu sirip dada, sirip perut, dan lengkung insang bagian luar dipisahkan dari tubuh ikan dengan cara memotong dari bagian pangkal tanpa merusak jari-jari lemah dan tapis insang ikan. Penghitungan bagian kiri dan bagian kanan organ- organ tersebut dilakukan di bawah mikroskop binokuler. Ikan yang organ tubuh berpasangan pada sisi kiri dan kanannya tidak tumbuh sama sekali, dipisahkan dari perhitungan asimetri dan dikelompokkan pada individu yang abnormal untuk menentukan tingkat abnormalitasnya. Cara menghitung karakter meristik bilateral tersebut di atas berpedoman pada Saanin (1968).

Hasil penghitungan jumlah jari-jari lemah sirip dada, sirip perut, dan jumlah tapis insang selanjutnya digunakan untuk menghitung nilai fluktuasi asimetri, baik besaran (magnitude) maupun bilangan (number), dengan menggunakan rumus yang dikemukakan oleh Leary et al. (1985), sebagai berikut:

$$
\mathrm{FA}_{\mathrm{m}}=\frac{\sum(\mathrm{L}-\mathrm{R})}{\mathrm{N}} \text { dan } \mathrm{FA}_{\mathrm{n}}=\frac{\sum \mathrm{Z}}{\mathrm{n}}
$$

Keterangan:

$\mathrm{FA}_{\mathrm{m}}$ : Fluktuasi asimetri magnitude (besaran)

$\mathrm{FA}_{\mathrm{n}}$ : Fluktuasi asimetri number (bilangan)

$L \quad$ : Jumlah organ sisi kiri

$\mathrm{R}$ : Jumlah organ sisi kanan

Z : Jumlah individu asimetri untuk ciri meristik tertentu

$\mathrm{N}, \mathrm{n}$ : Jumlah sampel

\section{HASIL DAN BAHASAN}

Gambar 1 menunjukkan karakter tapis insang yang mempunyai nilai fluktuasi asimetri bilangan $(0,79$ sampai 0,96 ) lebih tinggi dibandingkan karakter sirip dada dan sirip perut masing-masing 0,34 sampai

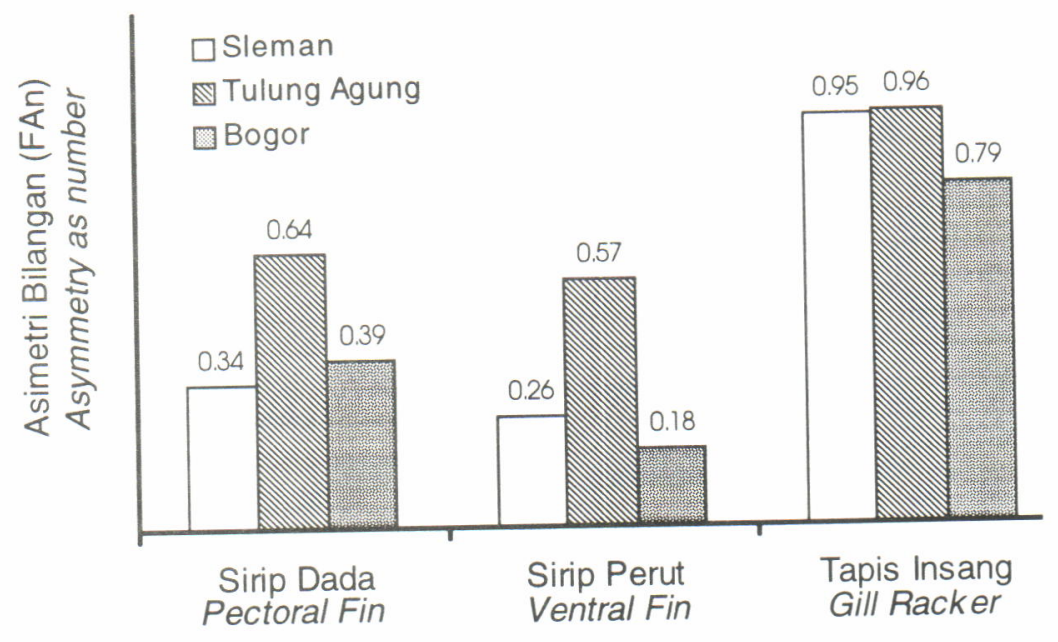

Karakter (Character)

Gambar 1. Nilai fluktuasi asimetri bilangan (number) lele dumbo yang berasal dari Sleman, Tulung Agung, dan Bogor

Figure 1. Fluctuating asymmetry number of dumbo catfish collected from Sleman, Tulung Agung, and Bogor 
dengan 0,64 dan 0,18 sampai dengan 0,57. Demikian pula pada Gambar 2, karakter tapis insang mempunyai nilai fluktuasi asimetri besaran (6,83 sampai dengan $6,97)$ yang lebih tinggi dibandingkan dengan karakter sirip dada $(0,52$ sampai dengan 1,13$)$ dan sirip perut $(0,21$ sampai dengan 0,99$)$.

Selanjutnya pada Gambar 3 ikan lele dumbo yang berasal dari Tulung Agung mempunyai nilai fluktuasi asimetri gabungan ketiga karakter meristik bilateral (overall) paling tinggi, baik untuk besaran $(8,93)$ maupun bilangan $(2,17)$. Sedangkan lele dumbo yang berasal dari Bogor mempunyai nilai fluktuasi asimetri yang paling rendah baik untuk besaran $(7,58)$ maupun bilangan $(1,36)$, dan lele dumbo yang berasal dari Sleman berada pada nilai di antara keduanya $(8,49$ dan 1,55).

Gambar 4 menunjukkan persentase jumlah individu yang tidak tumbuh sirip dada dan sirip perut pada kedua sisinya (abnormal). Lele dumbo yang berasal dari Sleman mempunyai abnormalitas yang paling tinggi, baik pada sirip dada $(1,33 \%)$ maupun sirip perut $(27,56 \%)$ yang kemudian diikuti oleh lele dumbo yang berasal dari Tulung Agung $(0,44 \%$ dan $3,11 \%)$. Sedangkan lele dumbo yang berasal dari Bogor abnormalitasnya paling rendah dan hanya ada pada sirip perut sebanyak $0,44 \%$.

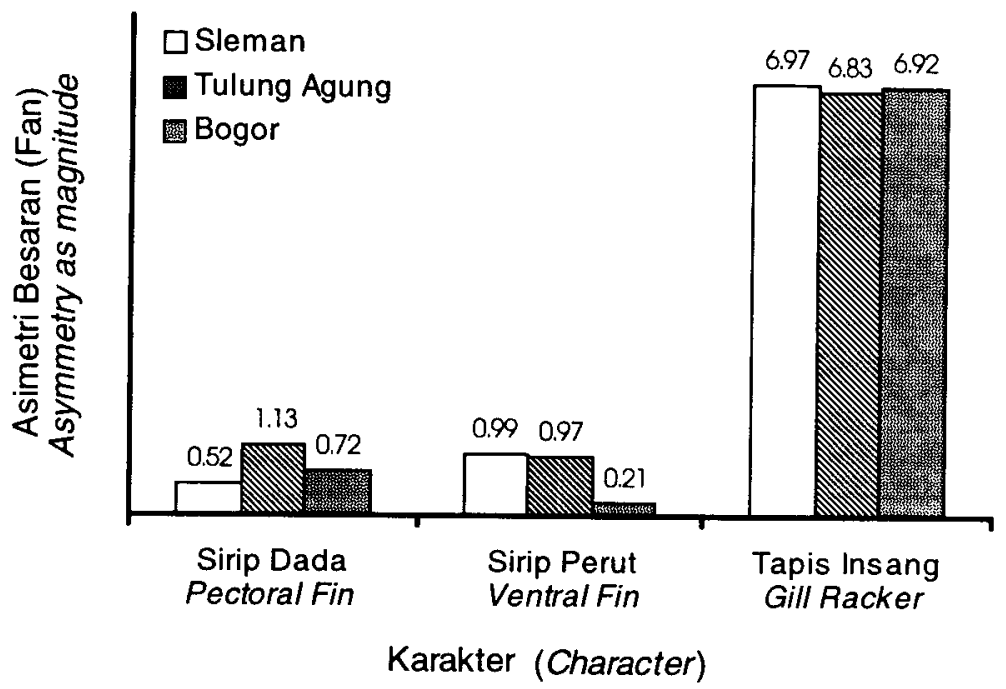

Gambar 2. Nilai fluktuasi asimetri besaran (magnitude) lele dumbo yang berasal dari Sleman, Tulung Agung, dan Bogor

Figure 2. Fluctuating asymmetry magnitude of dumbo catfish collected from Sleman, Tulung Agung, and Bogor

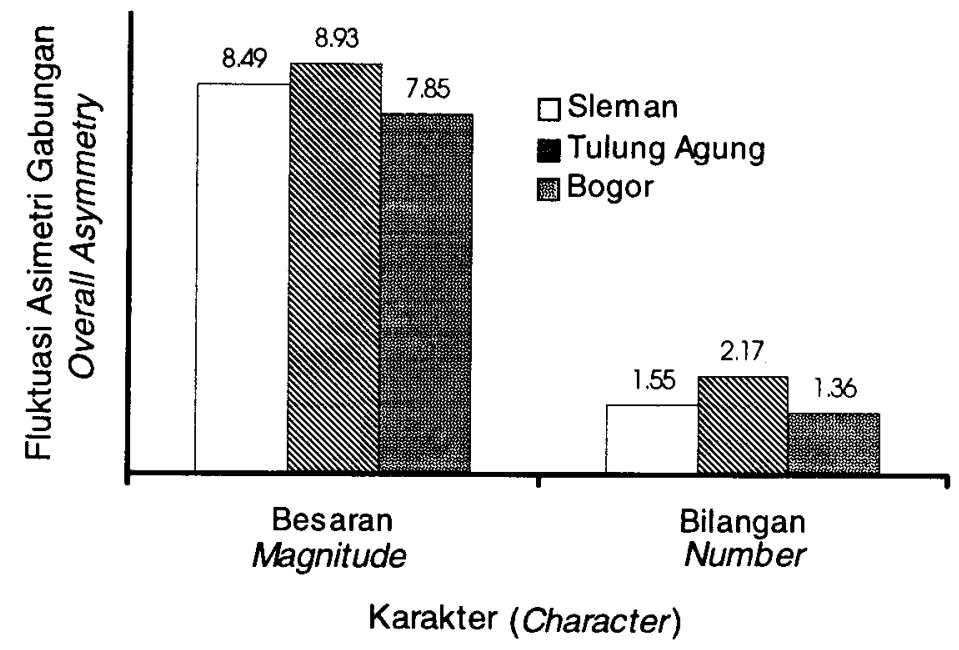

Gambar 3. Nilai fluktuasi asimetri bilangan (number) dan besaran (magnitude) untuk ketiga karakter meristik bilateral (overall) lele dumbo yang berasal dari Sleman, Tulung Agung, dan Bogor

Figure 3. Fluctuating asymmetry overall of dumbo catfish collected from Sleman, Tulung Agung, and Bogor 


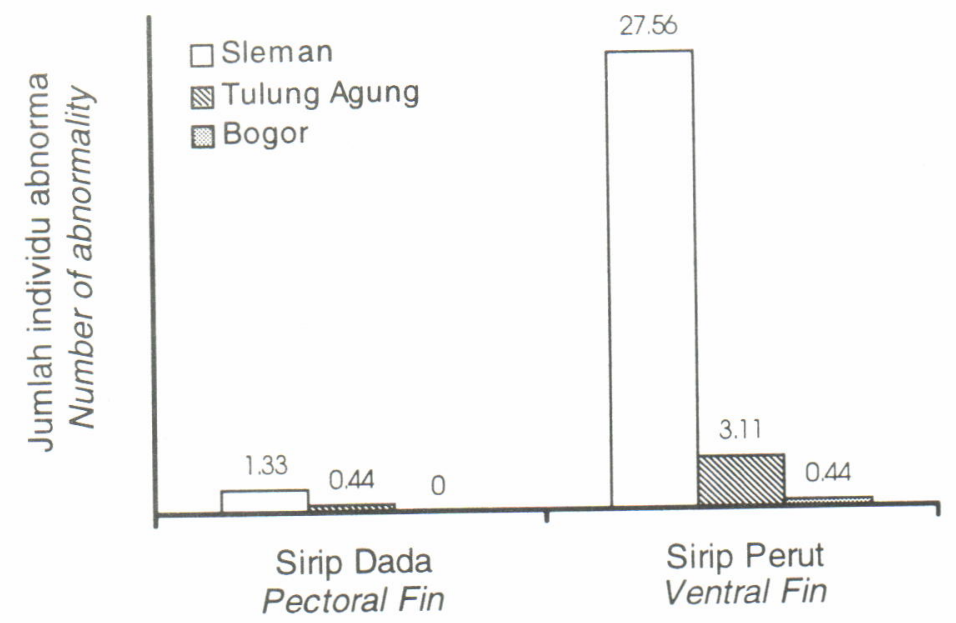

Karakter (Character)

Gambar 4. Persentase abnormalitas pada lele dumbo yang berasal dari Sleman, Tulung Agung, dan Bogor Figure 4. Abnormality percentages of dumbo catfish collected from Sleman, Tulung Agung, and Bogor

Tingginya nilai fluktuasi asimetri pada karakter tapis insang kemungkinan disebabkan oleh lebih banyaknya fungsi tapis insang, yang antara lain berperan dalam fungsi osmoregulasi, respirasi, metabolisme, dan ekskresi bahan-bahan yang tidak berguna, dibandingkan dengan fungsi s $_{\text {ip }}$ dada dan sirip perut yang hanya untuk bergerak (berenang). Beragamnya fungsi insang tersebut mengakibatkan tapis insang lebih peka terhadap berbagai perubahan dalam proses perkembangannya. Wilkins et al. (1995) pada pengamatan asimetri ikan salmon dan trout memperoleh hasil yang sama, yaitu nilai fluktuasi asimetri bilangan dan besaran karakter tapis insang $(0,65$ dan 0,86$)$ lebih besar dari karakter sirip dada $(0,32$ dan 0,68$)$ dan sirip perut $(0,37$ dan 0,40$)$.

Tingginya nilai fluktuasi asimetri pada lele dumbo yang berasal dari ketiga daerah tersebut kemungkinan besar adalah sebagai akibat silang-dalam yang kuat pada beberapa generasi lele dumbo. Pengamatan asimetri pada ikan mas G2N mitotik generasi pertama yang mengalami tekanan silang-dalam mempunyai nilai fluktuasi asimetri bilangan 2,55 dan besaran 3,64 (Sumantadinata et al., 1992).

Terjadinya silang-dalam pada lele dumbo tersebut disebabkan antara lain lele dumbo merupakan ikan hibrida yang tidak terdapat spesies murninya di perairan Indonesia. Oleh karena itu penggunaan induk selanjutnya dalam kegiatan budi daya relatif dekat kekerabatannya, karena berasal dari turunan generasi induk awal yang diintroduksi ke Indonesia.

Tekanan silang-dalam yang kuat dapat diakibatkan oleh perkawinan sekerabat dan penggunaan jumlah induk yang terbatas dalam setiap pemijahan
(Hardjamulia, 1999). Hasil pengamatan di tiga daerah sentra budi daya, pada umumnya kegiatan pemijahan lele dumbo menggunakan jumlah pasangan induk yang terbatas, yaitu satu sampai dengan dua pasang induk. Menurut Tave (1986) dalam kegiatan pemijahan, pasangan sejumlah induk yang memenuhi nilai pemijahan efektif $(\mathrm{Ne})$ adalah lebih dari 50 pasang yang dapat memperkecil terjadinya silang-dalam. Selain itu, sumber perolehan induk di daerah Tulung Agung dan Sleman pada umumnya adalah hasil seleksi dari keturunan induk generasi sebelumnya, sehingga induk yang dipijahkan sangat dekat hubungan kekerabatannya. Sedangkan untuk daerah Bogor, sumber perolehan induk untuk pemijahan didapat dari pembelian di pasar ikan yang didatangkan dari berbagai daerah sehingga kemungkinan lebih jauh hubungan kekerabatannya.

Sebagaimana halnya asimetri, tingginya abnormalitas kemungkinan besar merupakan akibat silang-dalam yang telah terjadi pada lele dumbo, terutama yang berasal dari Sleman.

\section{KESIMPULAN DAN SARAN}

\section{Kesimpulan}

1. Karakter tapis insang mengalami fluktuasi asimetri yang paling tinggi dibanding karakter sirip dada dan sirip perut.

2. Tingkat abnormalitas paling tinggi terdapat pada sirip perut.

3. Lele dumbo yang berasal dari ketiga daerah sentra budi daya di Pulau Jawa, yaitu Sleman, Tulung Agung, dan Bogor mempunyai nilai fluktuasi 
asimetri dan abnormalitas yang tinggi.

4. Lele dumbo yang berasal dari Bogor dengan fluktuasi asimetri dan abnormalitas paling rendah adalah lebih baik dibandingkan dengan lele dumbo yang berasal dari Tulung Agung dan Sleman.

\section{Saran}

Program perbaikan genetik pada lele dumbo melalui upaya peningkatan keragaman genetik induk yang dapat diperoleh dengan cara menggabung kembali karakter-karakter unggul dari populasipopulasi yang berasal dari berbagai lokasi, perlu dilakukan untuk meningkatkan stabilitas perkembangannya.

\section{DAFTAR PUSTAKA}

Hardjamulia, A. 1999. Pengelolaan dan penyebaran induk penjenis ikan air tawar mendukung pelepasan varietas. Makalah disampaikan pada Pertemuan Perekayasaan Teknologi Perbenihan Agribisnis Ikan Air Tawar, Payau, dan Laut. Direktorat Jenderal Perikanan, Departemen Pertanian, Jakarta.
Leary, R.F., F.W. Allendorf, and K.L. Knudsen. 1985. Development instability as an indicator of reduced genetic variation in hatchery trout. Trans. American Fish. Soc., 114: 230--235.

Rustidja. 1999. Perbaikan mutu genetik ikan lele dumbo dan cryopreservation. Makalah disampaikan pada Pertemuan Perekayasaan Teknologi Perbenihan Agribisnis Ikan Air Tawar, Payau, dan Laut. Direktorat Jenderal Perikanan, Departemen Pertanian, Jakarta.

Saanin, H. 1968. Taksonomi dan Kunci Identifikasi lkan. Binacipta, Bandung. $256 \mathrm{pp}$.

Sumantadinata, K., H. Arfah, dan K. Soewardi. 1992. Fenotip generasi pertama beberapa strain ikan mas (Cyprinus carpio L.) hasil pemurnian dengan metode ginogenesis. J. IImu Pertanian Indonesia, 2(2): 96-102.

Tave, D. 1986. Genetics for Fish Hatchery Managres. AVI Publishing Company, Inc., Westport, Connecticut.

Van Valen, L. 1962. A study of fluctuating asymmetry. Evolution, 16(2): 125--142.

Wilkins, N.P., E. Gosling, A. Curatolo, A. Linnane, C. Jordan, and H.P. Courtney. 1995. Fluctuating asymmetry in Atlantic salmon, European trout and their hybrids, including triploids. Aquaculture, 137: 77--85. 
